\title{
The Power of Proof against CCTV in Criminal Justice System
}

\section{Tegar kurnia Priambudi ${ }^{*}$ and Lathifah Hanim ${ }^{* *}$}

*) Students of Master of Law, Faculty of Law, Universitas Islam Sultan Agung Semarang, E-mail: tegarkurnia95@gmail.com

${ }^{* *}$ Faculty of Law, Universitas Islam Sultan Agung Semarang

\begin{abstract}
.
This study aims to determine and analyze the development of the proving power of CCTV in criminal justice, as well as the validity of CCTV as evidence in court.The research approach method used is normative juridical. This research uses qualitative methods with data collection techniques carried out by observation (observation), free in-depth interviews and is supported by literature study. Based on the research, it can be concluded that the function of CCTV recording is to strengthen the Judge's belief in describing the incident at the crime scene recorded in accordance with the facts which are reinforced by the Expert's conviction shown in the CCTV footage and strengthening trial evidence which serves to be used as 2 evidence in court because it is used as a clue and letter. The obstacles faced by the Judge in the process of proving premeditated murder through CCTV footage of the results that were displayed were unclear, due to the location of the CCTV.

Keywords: Power of Proof; CCTV; Evidence; Criminal Justice System.
\end{abstract}

\section{Introduction}

Current technological developments have a major impact on every aspect of human life. The existence of technology has been able to change behavior and change the era to be faster than before. The phenomenon of technological development has also changed various aspects of human life such as economic, social, cultural, political and legal life. ${ }^{1}$

CCTV is a video tool that is used to record events in a certain area to be displayed "Limited monitor" with limited publication coverage. The use of CCTV as a monitoring tool has begun to be applied in many places. Its existence can bring a sense of security to become a supervisor of locations or geographic spots that are difficult to reach by direct eye view. ${ }^{2}$

Electronic evidence, especially video recordings, has actually become commonplace in the practice of criminal proceedings in developed countries, especially in countries with the common law system. In Indonesia itself, several laws based on criminal (special criminal acts) have been regulated regarding this electronic data recording instrument, but what about general crimes where the criminal procedure uses the Criminal Procedure Code (KUHAP).

Article 184 of the Criminal Procedure Code, which becomes the umbrella law for criminal procedural law in Indonesia, only limits the five pieces of

\footnotetext{
${ }^{1}$ Edmon Makarim. (2003). Kompilasi Hukum Telematika. Jakarta : Raja Grafindo Persada. p. 5

2 Takasya Angela Tanauw Khristanto. (2016). Kedudukan Hukum CCTV Sebagai Alat Bukti Elektronik Setelah Terbitnya Putusan Mahkamah Konstitusi Nomor 20/Puu-Xiv/2016. Universitas Surabaya: Mahasiswi Magister Ilmu Hukum.
} 
evidence, namely witness testimony, expert testimony, letters, instructions, and statements of the defendant. ${ }^{3}$

This formulation is not able to accommodate the development of the existing society. So far, the position of video recordings in practice is still being debated regarding its recognition in criminal court evidence, but lately the role of electronic data recordings, especially these videos, can have value in the power of evidence.

The judiciary has a very important position and role in receiving, adjudicating and deciding cases submitted to it. In deciding a case, the court must pay attention to the evidence, not only in the lawsuit but also considering the existence of other evidence, such as witness testimony, instructions, and others.

The theory of evidence, which in English is called evidence theory, while in Dutch, is called bewijstheorie, is a theory that is often used, both by judges, lawyers, prosecutors and justice seekers in order to seek truth and justice.

Based on the background of this problem, the authors formulate the following problems: To what extentthe development of the proving power of CCTV in criminal justice? How is the validity of CCTV as evidence in court?

\section{Research methods}

The research approach method used is normative juridical. This research uses qualitative methods with data collection techniques carried out by observation, free in-depth interviews and is supported by literature study.

\section{Results and Discussion}

Judges as the main role of proof in the trial are required to adhere to the Criminal Procedure Code. If the law is incomplete or unclear, the judge must seek or find the law (rechtvinding). Legal discovery according to Sudikmo Mertokusumo. ${ }^{4}$ Defined:

"As a process of legal formation by judges or other legal officers who are assigned the task of implementing the law or applying general legal regulations to concrete legal events". 5

In a legal system, the aspect of law enforcement is the center of "activity" in legal life. Law enforcement in a broad sense includes activities to carry out and enforce the law against any violation or misconduct of the law committed by legal subjects, either through judicial procedures or through arbitration procedures and other dispute resolution mechanisms (alternative desputes or conflicts resolution).

Meanwhile, in a narrow sense, law enforcement involves taking action against any violations or deviations from statutory regulations, especially in a narrower way through the criminal justice system which involves the role of the police, prosecutors, advocates, or lawyers and judicial bodies.

\footnotetext{
${ }^{3}$ Act No. 8 of 1981 concerning the Criminal Procedure Code

${ }^{4}$ Sudikno Mertokusumo dan A. Pitlo. (1993). Bab-bab tentang Penemuan Hukum. Jakarta: Citra Aditya bakti. p. 37

${ }^{5}$ Lanka asmar dan Samsul fadli. (2019). Metode Penemuan Hukum Pembuktian elektronik dan CCTV pada Peradilan Pidana. Yogyakarta: UII Press. p. 7
} 
The criminal justice system known in Indonesia is a translation of "criminal justice system"A system developed by law practitioners in the United States. According to Marjono Reksodiputro, the criminal justice system is a crime control system consisting of the police, prosecutors and prisons. Crime control is a control system in a management approach.

The functions of the criminal justice system are first. Prevent crime. Second. Acting on the perpetrator of a criminal act by providing an understanding of the perpetrator of a criminal act where prevention is not effective. Third. Review of the legality of prevention and enforcement measures. Fourth. Court decisions to determine guilt or innocence of the detained person. Fifth. In the appropriate position against a person, money is found guilty. Sixth. Correction institutions by state instruments approved by the community for their behavior that has violated criminal law. ${ }^{6}$

The criminal justice system in Indonesia specifically adheres to:

- Principles of specialization, differentiation and competition.

- The principle of a trial that is fast, simple and low cost.

- The principle of the presumption of innocent.

- The principle of equality before the law, (equality before the law).

- The principle of "opportunity"

- The examination is open to the public

- The suspect/defendant is entitled to legal assistance

- The principles of the acquisator and the incusator (inquisitoir)

- Examination by the judge directly and verbally. ${ }^{7}$

In criminal proceedings, often the evidence is in the form of CCTV coupled with the information of a digital forensic expert to strengthen the authenticity of the CCTV footage. Whether CCTV and a digital forensic expert's statement are an integral part of the evidence or are a separate part, it is interesting to be reviewed in the next discussion.

The use of CCTV as evidence shows that the position of Closed Circuit Television as evidence in the judiciary in Indonesia cannot be separated from Act No. 19 of 2016 concerning Electronic Information and Transactions (UU ITE) and the Decision of the Constitutional Court Number 20/PUU-XIV/2016 that electronic evidence (including CCTV) must not only have formal and material requirements, and must also be interpreted by law enforcers at the request of law enforcers.

Prior to the Constitutional Court's decision, there had been legal questions regarding the position of electronic information and electronic documents in criminal procedural law in Indonesia. If we analyze the provisions of Article 5 paragraph (2) of Act No. 19 Year 2016 concerning Electronic Information and Transactions (UU ITE), it is said that both are extensions of valid evidence in accordance with applicable procedural law. Article 5 paragraph (2) of Act No. 19 of 2016 concerning Electronic Information and Transactions (UU ITE) regulates that Electronic Information and/or Electronic Documents and/or their printouts are an

\footnotetext{
${ }^{6}$ Tolib Effendi. (2013). Sistem Peradilan Pidana. Yogyakarta: pustaka yustisia. p. 10-14

7 Marwan Effendy. (2012). Sistem Peradilan Pidana Tinjauan Terhadap Perkembangan Hukum Pidana. Jakarta: Referensi. p. 5-6
} 
extension of legal evidence in accordance with applicable procedural law. in Indonesia.

There is no valid explanation regarding what is meant by the expansion, so the question arises whether the expansion is interpreted as an addition to evidence or is part of existing evidence. In Article 184 of Act No. 8 of 1981 concerning the Criminal Procedure Code (KUHAP) there are five pieces of evidence, namely witness statements, expert statements, letters, instructions and statements of the defendants and if the expansion is meant to be added, the evidence in criminal procedural law in Indonesia in general becomes more of five ${ }^{8}$.

The electronic information and electronic data can be used as a basis for evidence of guidance for the Panel of Judges. Then if the expansion is interpreted as part of existing evidence, then the evidence in criminal law generally remains at five, however, both electronic information and electronic documents can be included in evidence or documentary evidence.

Several things that can be revealed and proven with electronic evidence include identifying objects (electronic evidence), determining the relationship between electronic evidence and the perpetrator who is suspected of committing a criminal act, reconstructing the past, protecting the innocent and preparing experts in court

The steps through CCTV footage in digging up evidence in the form of electronic evidence so that it can be used in proving a criminal case is not easy because of the characteristics attached to it. After the principles and stages are fulfilled (it can be said as formal requirements), then the material requirements are met, namely the relationship between the contents of electronic evidence and proof of a criminal case.

\section{Closing}

The function of CCTV footage is to strengthen the Judge's belief in describing the incident at the crime scene recorded in accordance with the facts which are reinforced by the Expert's conviction shown in the CCTV footage and strengthen trial evidence which serves to be used as 2 evidence in court because it is used as instructions and letters. The obstacles faced by the Judge in the process of proving premeditated murder through CCTV footage of the results that were displayed were unclear, due to the location of the CCTV.

Based on the above conclusions, the author provides the following suggestions: For law enforcement officials, in determining a cyber crime crime so that they can listen to expert testimony starting from the level of investigation to the level of case resolution at court, so that the arguments and interpretations used are no different and the Judge in deciding a cyber crime case can have conviction as the norm. applicable law and decide cases fairly.

\footnotetext{
8 Soerodibroto soenarto. (2003). KUHP dan KUHAP Dilengkapi Yurisprudensi Mahkamah Agung dan Hoge Raad edisi kelima. Jakarta: RajaGrafindo Persada. p. 438.
} 


\section{References}

\section{Journal:}

[1] Takasya Angela Tanauw Khristanto. (2016). Kedudukan Hukum CCTV Sebagai Alat Bukti Elektronik Setelah Terbitnya Putusan Mahkamah Konstitusi Nomor 20/Puu-Xiv/2016. Universitas Surabaya: Mahasiswi Magister Ilmu Hukum.

\section{Books:}

[1] Andi Hamzah. (2010). Hukum Acara Pidana Indonesia. Jakarta: Sinar Grafika. edisi kedua.

[2] Asmar Lanka dan samsul fadli. (2019). Penemuan Hukum Pembuktian Elektronik dan CCTV pada Peradilan pidana. Yogyakarta: Uii Press.

[3] Djoko Prakoso. (1988). Alat Bukti dan Kekuatan Pembuktian didalam Proses Pidana. Yogyakarta: Liberty.

[4] Edmon Makarim. (2003). Kompilasi Hukum Telematika. Jakarta: Raja Grafindo Persada.

[5] Lanka asmar dan Samsul fadli. (2019). Metode Penemuan Hukum Pembuktian elektronik dan CCTV pada Peradilan Pidana. Yogyakarta: UII Press.

[6] Marwan Effendy. (2012). Sistem Peradilan Pidana Tinjauan Terhadap Perkembangan Hukum Pidana. Jakarta: Referensi.

[7] Peter Mahmud marzuki. (2011). Penelitian Hukum. Jakarta: Prenada media Group.

[8] Soerodibroto Soenarto. (2003). KUHP dan KUHAP Dilengkapi Yurisprudensi Mahkamah Agung dan Hoge Raad edisi kelima. Jakarta: RajaGrafindo Persada.

[9] Sudikno Mertokusumo dan A. Pitlo. (1993). Bab-bab tentang Penemuan Hukum. Jakarta: Citra Aditya bakti.

[10] Sudikno Mertokusumo. (2012). Teori Hukum. Yogyakarta: Cahaya Atma Pustaka.

[11] Suteki, Galang Taufani. (2010). Metode Penelitian Hukum. Depok: Rajawali Pers.

[12] Tolib Effendi. (2013). Sistem Peradilan Pidana. Yogyakarta: Pustaka Yustisia. 